\title{
AN INTERPOLATION OF JENSEN'S INEQUALITY AND ITS APPLICATIONS TO MEAN INEQUALITIES
}

\author{
JADRANKA MićIĆ HOT AND YUKI SEO
}

Abstract. In this paper, we show operator versions of the inequality due to Cho, Matić and Pečarić in connection to Jensen's inequality for convex functions. As applications, we obtain an interpolation of the weighted arithmetic-geometric mean inequality for the Karcher mean of positive invertible operators on a Hilbert space. Moreover, we obtain an interpolation between the quasi-arithmetic means.

Mathematics subject classification (2010): Primary 47A63, secondary 47A64.

Keywords and phrases: Jensen's inequality, positive linear map, convex function, Karcher mean, quasiarithmetic mean.

\section{REFERENCES}

[1] Y. J. Cho, M. MATIĆ AND J. PeČARIĆ, Two mappings in connection to Jensen's inequality, Panamerican Math. J. 12 (2002), 43-50.

[2] S. S. Dragomir, Two mappings in connection to Hadamard's inequalities, J. Math. Anal. Appl. 167 (1992), 49-56.

[3] T. Furuta, J. Mićić Hot, J. Pečarić And Y. Seo, Mond-Pečarić Method in Operator Inequalities, Zagreb, Element, 2005.

[4] J. LAWSON AND Y. LIM, Karcher means and Karcher equations of positive definite operators, Trans. Amer. Math. Soc., Series B, 1 (2014), 1-22.

[5] J. MiĆIĆ AND J. PEČARIĆ, Some mappings related to Levinson's inequality for Hilbert space operators, accepted in Filomat, http://journal.pmf.ni.ac.rs/filomat/index.php/filomat/ issue/view/6.

[6] J. MićIĆ, J. PEČARIĆ AND Y. SEO, Order among quasi-arithmetic means of positive operators, Math. Reports 14 (2012), 71-86.

[7] J. MićIĆ Hot, J. PeČARIĆ AND Y. SEO, An estimate of quasi-arithmetic mean for convex functions, Sci. Math. Japon., online, e-2012, 237-247.

[8] B. MOND AND J. PEČARIĆ, On Jensen's inequality for operator convex functions, Houston J. Math. 21 (1995), 739-753. 